\title{
Studi Preferensi Konsep Integrasi Angkutan Feeder Suroboyo Bus Rute Purabaya-Rajawali dengan Metode Conjoint
}

\author{
Biyan Shandy Paramayudha dan Ketut Dewi Martha Erli Handayeni \\ Departemen Perencanaan Wilayah dan Kota, Institut Teknologi Sepuluh Nopember (ITS) \\ e-mail: erli.martha@gmail.com
}

\begin{abstract}
Abstrak-Salah satu permasalahan yang terjadi di Kota Surabaya adalah kurangnya minat masyarakat untuk menggunakan angkutan umum. Untuk menghadapi permasalahan tersebut, Pemerintah Kota Surabaya telah mengembangkan dan merencanakan Suroboyo Bus beserta jaringan feeder untuk mendukungnya. Upaya tersebut berpotensi untuk menjawab permasalahan yang ada apabila didukung dengan penerapan konsep integrasi angkutan umum. Konsep integrasi tersebut dapat diterapkan kepada Suroboyo Bus dan layanan feeder, di mana feeder tersebut merupakan feeder yang berbasis terminal. Untuk menciptakan konsep integrasi antara Suroboyo Bus yang optimal, diperlukan studi preferensi masyarakat. Oleh karena itu penelitian ini ditujukan untuk menggali preferensi masyarakat tersebut dengan menggunakan metode Conjoint. Hasil penelitian menunjukkan bahwa masyarakat memlilih konsep integrasi yang meliputi desain stasiun/titik transfer yang mempermudah perpindahan ke angkutan umum, fasilitas pejalan kaki dengan prioritas kenyamanan, jaringan yang terhubung ke seluruh angkutan, penyediaan informasi rute secara elektronik, penyediaan informasi jadwal secara non-elektronik, pemberian identitas angkutan dengan dua pembeda tariff yang terintegrasi dengan Suroboyo Bus, keamaanan yang ditunjang dengan CCTV, kenyamanan yang ditunjang dari fasilitas di dalam angkutan, serta waktu tunggu maksimal 26 menit. Selain itu, penerapan konsep integrasi disarankan untuk memiliki prioritas dalam aspek desain stasiun/titik transfer, penyediaan informasi rute, dan waktu tungu.
\end{abstract}

Kata Kunci-Integrasi Feeder, Persepsi, Conjoint.

\section{PENDAHULUAN}

$\mathrm{S}$ ALAH satu upaya untuk mengurangi kemacetan adalah dengan mempromosikan angkutan umum yang bisa mengambil alih sebagian perjalanan-perjalanan yang dilakukan dengan kendaraan pribadi [1]. Hal tersebut menjadi sebuah tantangan mengingat kelebihan yang dimiliki oleh kendaraan pribadi dibandingkan dengan angkutan umum seperti perjalanan "door to door".

Penggunaan kendaran pribadi di Kota Surabaya masih sangat dominan. Dalam Laporan Akhir Rencana Sistem Angkutan Umum bagian karakteristik sosial ekonomi zona asal dan tujuan, disebutkan bahwa jenis moda yang paling banyak digunakan adalah sepeda motor dengan rasio $72,8 \%$, sedangkan penggunaan angkutan umum hanya sebesar $8,79 \%$ [2]. Untuk menanggapi hal tersebut, Pemerintah Kota Surabaya telah menyusun strategi meningkatkan jumlah pengguna angkutan umum massal dan berkurangnya penggunaan kendaraan pribadi di dalam Rencana Jangka Menengah Daerah (RPJMD) Kota Surabaya 2016- 2021. Strategi tersebut adalah upaya untuk mencapai tujuan penyediaan dan optimalisasi sistem angkutan umum massal yang berkualitas dan ramah lingkungan.
Tabel 1.

Variabel Penelitian

\begin{tabular}{|c|c|c|c|}
\hline No. & Aspek & Variabel & $\begin{array}{l}\text { Definisi } \\
\text { Operasional }\end{array}$ \\
\hline \multirow[t]{3}{*}{1.} & $\begin{array}{l}\text { Integrasi } \\
\text { Fisik }\end{array}$ & $\begin{array}{l}\text { Desain } \\
\text { Stasiun/Titik } \\
\text { Transfer }\end{array}$ & $\begin{array}{l}\text { Komponen yang } \\
\text { menyusun tempat } \\
\text { dimana orang bisa } \\
\text { beripindah moda } \\
\text { transportasi lain }\end{array}$ \\
\hline & & $\begin{array}{l}\text { Fasilitas Pejalan } \\
\text { Kaki }\end{array}$ & $\begin{array}{l}\text { Adanya } \\
\text { kelengkapan } \\
\text { fasilitas pejalan } \\
\text { kaki }\end{array}$ \\
\hline & & Jaringan & $\begin{array}{l}\text { Adanya rute atau } \\
\text { fasilitas berpindah } \\
\text { yang mendukung } \\
\text { rute utama }\end{array}$ \\
\hline \multirow[t]{3}{*}{2.} & $\begin{array}{l}\text { Integrasi } \\
\text { Operasional }\end{array}$ & $\begin{array}{l}\text { Penyediaan } \\
\text { Informasi Rute }\end{array}$ & $\begin{array}{l}\text { Fasilitas-fasilitas } \\
\text { yang memberikan } \\
\text { informasi } \\
\text { rute/trayek } \\
\text { angkutan umum }\end{array}$ \\
\hline & & $\begin{array}{l}\text { Penyediaan } \\
\text { Informasi Jadwal }\end{array}$ & $\begin{array}{l}\text { Jadwal yang } \\
\text { tersinkronisasi } \\
\text { antara angkutan } \\
\text { umum dengan rute } \\
\text { atau moda yang } \\
\text { berbeda }\end{array}$ \\
\hline & & Penyediaan Tariff & $\begin{array}{lr}\text { Adanya } & \text { sistem } \\
\text { layanan satu } & \text { kartu } \\
\text { yang } & \text { bisa } \\
\text { digunakan dalam } \\
\text { pembayaran di } \\
\text { moda transportasi } \\
\text { yang berbeda }\end{array}$ \\
\hline \multirow[t]{3}{*}{3.} & $\begin{array}{l}\text { Integrasi } \\
\text { Sosial }\end{array}$ & Keamanan & $\begin{array}{l}\text { Upaya-upaya untuk } \\
\text { mencegah tindak } \\
\text { kriminal }\end{array}$ \\
\hline & & Kenyamanan & $\begin{array}{l}\text { Upaya-upaya untuk } \\
\text { meningkatkan } \\
\text { kenyamanan on } \\
\text { board }\end{array}$ \\
\hline & & Waktu Tunggu & $\begin{array}{l}\text { Waktu tunggu yang } \\
\text { relatif singkat, yaitu } \\
\text { dibawah } 20 \text { menit }\end{array}$ \\
\hline
\end{tabular}

Selain dari RPJMD Kota Surabaya 2016 - 2021, Laporan Akhir Rencana Sistem Angkutan Umum juga memuat konsep trunk line dan feeder line sebagai pendukung Angkutan Massal Cepat untuk optimalisasi sistem angkutan umum. Perwujudan trunk line dari dokumen tersebut adalah Suroboyo Bus yang beroperasi mulai April 2018 dengan rute Purabaya -Rajawali dan rute ITS - UNESA. Sedangkan feeder line yang dimaksud berupa berupa rute feeder berbasis terminal yang terdiri atas 11 terminal yang tersebar di 12 kecamatan di Kota Surabaya.

Kunci dari integrasi angkutan umum adalah penentuan hierarki yang bisa mengidentifikasi angkutan trunk dan 
Tabel 2.

Atribut dan Level dari Variabel-variabel Integrasi

\begin{tabular}{|c|c|c|c|}
\hline No. & Aspek & Atribut & Level \\
\hline 1 & & $\begin{array}{l}\text { Desain } \\
\text { Stasiun/titik } \\
\text { transfer }\end{array}$ & $\begin{array}{l}\text { Memudahkan } \\
\text { perpindahan ke } \\
\text { kendaaraan pribadi } \\
\text { Memudahkan } \\
\text { perpindahan ke } \\
\text { angkutan umum }\end{array}$ \\
\hline 2 & $\begin{array}{l}\text { Integrasi } \\
\text { Fisik }\end{array}$ & $\begin{array}{l}\text { Fasilitas pejalan } \\
\text { kaki }\end{array}$ & $\begin{array}{l}\text { Prioritas keamanan } \\
\text { Prioritas } \\
\text { kenyamanan }\end{array}$ \\
\hline 3 & & Jaringan & $\begin{array}{l}\text { Terhubung dengan } \\
\text { seluruh angkutan } \\
\text { Terhubung dengan } \\
\text { seluruh angkutan } \\
\text { dan park and ride }\end{array}$ \\
\hline 4 & & $\begin{array}{l}\text { Penyediaan } \\
\text { Informasi Rute }\end{array}$ & $\begin{array}{l}\text { Secara Elektronik } \\
\text { Secara Non- } \\
\text { elektronik }\end{array}$ \\
\hline 5 & & $\begin{array}{l}\text { Penyediaan } \\
\text { Informasi Jadwal }\end{array}$ & $\begin{array}{l}\text { Secara Elektronik } \\
\text { Secara Non- } \\
\text { elektronik }\end{array}$ \\
\hline 6 & $\begin{array}{l}\text { Integrasi } \\
\text { Operasional }\end{array}$ & $\begin{array}{l}\text { Penyediaan } \\
\text { Informasi Signage }\end{array}$ & $\begin{array}{l}\text { Satu Pembeda } \\
\text { Dua Pembeda } \\
\text { Terintegrasi dengan } \\
\text { Suroboyo Bus }\end{array}$ \\
\hline 7 & & Penyediaan tarriff & $\begin{array}{l}\text { Terintegrasi dengan } \\
\text { Suroboyo Bus dan } \\
\text { Mikrolet } \\
\text { CCTV }\end{array}$ \\
\hline 8 & & Keamanan & $\begin{array}{l}\text { CCTV dan } \\
\text { pemisahan tempat } \\
\text { duduk }\end{array}$ \\
\hline 9 & $\begin{array}{l}\text { Integrasi } \\
\text { Sosial }\end{array}$ & Kenyamanan & $\begin{array}{l}\text { Ditunjang dari } \\
\text { fasilitas di dalam } \\
\text { angkutan } \\
\text { Ditunjang dari } \\
\text { keramahan dan } \\
\text { keahlian } \\
\text { awak/pengemudi }\end{array}$ \\
\hline 10 & & Waktu Tunggu & $\begin{array}{l}\text { Maksimal } 15 \text { Menit } \\
\text { Maksimal } 26 \text { Menit }\end{array}$ \\
\hline
\end{tabular}

angkutan feeder untuk asal-tujuan yang berbeda. Dalam konteks pelayanan transportasi umum, integrasi digunakan sebagai solusi keberlanjutan perjalanan door to door [3]. Integrasi angkutan umum terbagi dalam beberapa aspek. Salah satunya adalah Integrasi fisik yang merupakan integrasi dari fisik infrastruktur yang ada seperti bentuk desain stasiun, lokasi fasilitas, akses ke fasilitas, serta koordinasi pegerakan kendaraan [4]. Selain itu juga terdapat juga integrasi operasional yaitu koordinasi dari sistem transit dengan interupsi waktu dan ruang yang minimum [4]. Integrasi operasional dapat ditunjukkan oleh beberapa karakteristik seperti biaya dan penyediaan tiket yang terintegrasi, penyediaan informasi penumpang yang terintegrasi, serta jadwal yang terkoordinasi [5]. Integrasi transportasi umum dipengaruhi oleh sikap dan perilaku masyarakat [6], sehingga masyarakat perlu dipertimbangkan dalam menciptakan integrasi angkutan umum. Kriteria sosial juga merupakan bagian dari kriteria transportasi intermodal dan terdiri atas kenyamanan, keamanan, dan keandalan [7]. Kriteria sosial yang merujuk kepada masyarakat juga terkait dengan perspektif pengguna yang meliputi kemudahan akses, waktu perjalanan yang kompetitif, kemudahan, keamanan, dan kenyamanan [5][7].

Masalah penggunaan kendaraan pribadi di Kota Surabaya perlu diatasi dengan optimalisasi sistem angkutan umum yang ada. Sistem angkutan umum tersebut diwujudkan dalam
Tabel 3

Stimuli/Kombinasi untuk Aspek Integrasi Fisik

\begin{tabular}{|c|c|c|c|c|}
\hline $\begin{array}{l}\text { Pilih- } \\
\text { an }\end{array}$ & $\begin{array}{l}\text { Desain } \\
\text { Stasiun/Titik } \\
\text { Transfer }\end{array}$ & $\begin{array}{l}\text { Fasilitas } \\
\text { Pejalan Kaki }\end{array}$ & Jaringan & $\begin{array}{l}\text { Rank- } \\
\text { ing }\end{array}$ \\
\hline A & $\begin{array}{l}\text { Memudahkan } \\
\text { perpindahan ke } \\
\text { kendaaraan } \\
\text { pribadi }\end{array}$ & $\begin{array}{l}\text { Prioritas } \\
\text { Keamanan }\end{array}$ & $\begin{array}{l}\text { Terhubung } \\
\text { seluruh } \\
\text { angkutan }\end{array}$ & \\
\hline B & $\begin{array}{l}\text { Memudahkan } \\
\text { perpindahan ke } \\
\text { kendaaraan } \\
\text { pribadi }\end{array}$ & $\begin{array}{l}\text { Prioritas } \\
\text { Keamanan }\end{array}$ & $\begin{array}{l}\text { Terhubung } \\
\text { seluruh } \\
\text { angkutan } \\
\text { dan park } \\
\text { and ride }\end{array}$ & \\
\hline $\mathrm{C}$ & $\begin{array}{l}\text { Memudahkan } \\
\text { perpindahan ke } \\
\text { kendaaraan } \\
\text { pribadi }\end{array}$ & $\begin{array}{l}\text { Prioritas } \\
\text { Kenyamanan }\end{array}$ & $\begin{array}{l}\text { Terhubung } \\
\text { seluruh } \\
\text { angkutan }\end{array}$ & \\
\hline D & $\begin{array}{l}\text { Memudahkan } \\
\text { perpindahan ke } \\
\text { kendaaraan } \\
\text { pribadi }\end{array}$ & $\begin{array}{l}\text { Prioritas } \\
\text { Kenyamanan }\end{array}$ & $\begin{array}{l}\text { Terhubung } \\
\text { seluruh } \\
\text { angkutan } \\
\text { dan park } \\
\text { and ride }\end{array}$ & \\
\hline E & $\begin{array}{l}\text { Memudahkan } \\
\text { perpindahan ke } \\
\text { angkutan } \\
\text { umum }\end{array}$ & $\begin{array}{l}\text { Prioritas } \\
\text { Kenyamanan }\end{array}$ & $\begin{array}{l}\text { Terhubung } \\
\text { seluruh } \\
\text { angkutan }\end{array}$ & \\
\hline $\mathrm{F}$ & $\begin{array}{l}\text { Memudahkan } \\
\text { perpindahan ke } \\
\text { angkutan } \\
\text { umum }\end{array}$ & $\begin{array}{l}\text { Prioritas } \\
\text { Keamanan }\end{array}$ & $\begin{array}{l}\text { Terhubung } \\
\text { seluruh } \\
\text { angkutan } \\
\text { dan park } \\
\text { and ride }\end{array}$ & \\
\hline G & $\begin{array}{l}\text { Memudahkan } \\
\text { perpindahan ke } \\
\text { angkutan } \\
\text { umum }\end{array}$ & $\begin{array}{l}\text { Prioritas } \\
\text { Kenyamanan }\end{array}$ & $\begin{array}{l}\text { Terhubung } \\
\text { seluruh } \\
\text { angkutan } \\
\text { dan park } \\
\text { and ride }\end{array}$ & \\
\hline $\mathrm{H}$ & $\begin{array}{l}\text { Memudahkan } \\
\text { perpindahan ke } \\
\text { angkutan } \\
\text { umum }\end{array}$ & $\begin{array}{l}\text { Prioritas } \\
\text { Keamanan }\end{array}$ & $\begin{array}{l}\text { Terhubung } \\
\text { seluruh } \\
\text { angkutan }\end{array}$ & \\
\hline
\end{tabular}

layanan Suroboyo Bus beserta angkutan feeder yang mendukungnya. Oleh karena itu penelitian ini dilakukan untuk mengeksplorasi pengembangan feeder Suroboyo Bus berbasis konsep integrasi yang sesuai dengan preferensi masyarakat.

\section{METODE PENELITIAN}

\section{A. Variabel Penelitian}

Variabel di dalam penelitian ini merupakan hasil sintesa pustaka dari tinjauan pustaka yang terkait dengan konsep integrasi transportasi umum. Dari beberapa sumber terkait integrasi transportasi umum, Tabel 1 adalah variabel yang digunakan di dalam penelitian ini.

\section{B. Metode Pengumpulan Data}

Penelitian ini menggunakan metode pengumpulan data primer dan sekunder. Data sekunder dalam penelitian ini berupa dokumen yang bersumber dari Dinas Kependudukan dan Catatan Sipil Kota Surabaya serta Dinas Perhubungan Kota Surabaya. Pengumpulan data primer dilakukan melalui wawancara terhadap personel Dinas Perhubungan Kota Surabaya dan penyebaran kuisioner kepada masyarakat. Populasi di dalam penelitian ini, dibagi menjadi dua segmen yaitu segmen masyarakat dan segmen pemerintah. Segmen pemerintah terdiri atas pihak pemerintah yang bertanggung jawab atas operasional Suroboyo Bus beserta angkutan umum lain di Surabaya secara keseluruhan. Segmen masyarakat dibagi menjadi dua kelompok yaitu penumpang Suroboyo Bus dan non-penumpang Suroboyo Bus. Kelompok non- 
Tabel 4.

Stimuli/Kombinasi untuk Aspek Integrasi Operasional

\begin{tabular}{|c|c|c|c|c|c|}
\hline Pilihan & $\begin{array}{l}\text { Penyediaan } \\
\text { Informasi rute }\end{array}$ & $\begin{array}{l}\text { Penyedia-an } \\
\text { Informasi Jadwal }\end{array}$ & $\begin{array}{l}\text { Penyedia-an } \\
\text { Informasi Signage }\end{array}$ & Penyediaan Tarif & Ranking \\
\hline A & Elektronik & Elektronik & Satu Pembeda & $\begin{array}{l}\text { Terintegrasi dengan } \\
\text { Suroboyo Bus dan } \\
\text { Mikrolet }\end{array}$ & \\
\hline B & Non Elektronik & Non Elektronik & Satu Pembeda & $\begin{array}{l}\text { Terintregrasi dengan } \\
\text { Suroboyo Bus }\end{array}$ & \\
\hline $\mathrm{C}$ & Non Elektronik & Elektronik & Dua Pembeda & $\begin{array}{l}\text { Terintregrasi dengan } \\
\text { Suroboyo Bus } \\
\text { Terintegrasi dengan }\end{array}$ & \\
\hline $\mathrm{D}$ & Non Elektronik & Non Elektronik & Dua Pembeda & $\begin{array}{l}\text { Suroboyo Bus dan } \\
\text { Mikrolet } \\
\text { Terintegrasi dengan }\end{array}$ & \\
\hline $\mathrm{E}$ & Non Elektronik & Elektronik & Satu Pembeda & $\begin{array}{l}\text { Suroboyo Bus dan } \\
\text { Mikrolet }\end{array}$ & \\
\hline $\mathrm{F}$ & Elektronik & Elektronik & Dua Pembeda & $\begin{array}{l}\text { Terintregrasi dengan } \\
\text { Suroboyo Bus } \\
\text { Terintegrasi dengan }\end{array}$ & \\
\hline G & Elektronik & Non Elektronik & Dua Pembeda & $\begin{array}{l}\text { Suroboyo Bus dan } \\
\text { Mikrolet }\end{array}$ & \\
\hline $\mathrm{H}$ & Elektronik & Non Elektronik & Satu Pembeda & $\begin{array}{l}\text { Terintregrasi dengan } \\
\text { Suroboyo Bus }\end{array}$ & \\
\hline
\end{tabular}

penumapng Suroboyo Bus yang dimaksud adalah masyarakat yang tinggal di kecamatan yang dilewati rute Suroboyo Bus dan/atau rute angkutan feeder yang direncanakan.

Setiap segmen dari populasi memiliki teknik sampling tersendiri. Untuk segmen pemerintah, sampling yang digunakan adalah purposive sampling. Purposive sampling digunakan untuk mencari informasi pengembangan feeder Suroboyo Bus yang berkaitan dengan kriteria-kriteria integrasi. Metode sampling tersebut digunakan karena adanya informasi spesifik yang dibutuhkan dari informan/narasumber dengan kualitas spesifik. Hasil dari purposive sampling yang dilakukan meliputi lima narasumber/informan yang terdiri atas.

1. Kepala Seksi Angkutan Jalan Dinas Perhubungan Kota Surabaya

2. Kepala Bidang Angkutan Dinas Perhubungan Kota Surabaya

3. Kepala Bidang Lalu Lintas Dinas Perhubungan Kota Surabaya

4. Kepala Bidang Sarana dan Prasarana Dinas Perhubungan Kota Surabaya

5. Kepala Dinas Perhubungan Kota Surabaya

Pada segmen masyarakat, rumus yang digunakan untuk menentukan ukuran sampel adalah dengan menggunakan rumus Slovin. Dalam penghitungan sampel, batas toleransi error yang digunakan adalah $10 \%$. Batas tersebut ditentukan atas ketersediaan waktu dan sumber daya yang ada. Rumus slovin yang digunakan di dalam penelitian ini dapat dijelaskan sebagai berikut.

Keterangan:

$$
n=\frac{N}{1+N e^{2}}
$$

$\mathrm{n}=$ jumlah sampel

$\mathrm{N}=$ jumlah populasi

e = batas toleransi error $(10 \%)$

Penggunaan rumus slovin tersebut dilakukan pada masingmasing kelompok penumpang Suroboyo Bus serta nonpenumpang Suroboyo Bus.

Metode pengambilan sampel untuk kelompok penumpang Suroboyo Bus dilakukan dengan cara simple random sampling. Metode tersebut digunakan karena sifat penumpang Suroboyo Bus yang homogen. Penggunaan metode ini memberikan responden peluang yang sama untuk dipilih.

Kelompok non-penumpang Suroboyo Bus memiliki teknik pengambilan sampel yang berbeda, yaitu melalui stratified random sampling. Metode ini dilakukan untuk mendapatkan sampel yang lebih representatif, mengingat responden dalam kelompok tersebut tersebar di wilayah yang luas (12 kecamatan). Pengambilan jumlah sampel untuk setiap kecamatan dilakukan secara proporsional dengan perbandingan antara luas satu kecamatan dengan luas total dari seluruh kecamatan yang termasuk dalam penelitian ini.

\section{Metode Analisis}

Penelitian ini menggunakan metode analisis Conjoint. Analisis Conjoint adalah adalah teknik multivariat yang digunakan secara khusus untuk mengetahui bagaimana preferensi konsumen terhadap produk barang atau jasa [8]. Dalam konteks penelitian ini, konsumen yang dimaksud adalah masyarakat yang menilai layanan angkutan feeder Suroboyo Bus yang direncanakan. Masyarakat tersebut akan menilai atribut-atribut terkait pengembangan feeder Suroboyo Bus, sehingga preferensi masyarakat bisa didapatkan. Proses dari conjoint analysis meliputi langkah langkah sebagai berikut

1) Penentuan atribut berdasarkan variabel yang ditentukan beserta pilihan/tingkatan di setiap atribut yang berupa level.

Penentuan atribut dan level pada tahap ini dilakukan melalui teknik analisis Content yang merupakan metode penelitian untuk mengambil kesumpulan yang valid dan bisa direplikasi dari teks (atau materi penting lainnya) yang sesuai dengan konteks penggunaannya [9].Metode ini digunakan untuk menyediakan pilihan-pilihan lanyanan feeder Suroboyo Bus kepada masyarakat untuk dipilih pada proses selanjutnya.

2) Pembuatan kombinasi atribut atau stimuli yang nantinya akan dinilai oleh responden.

Pembuatan kombinasi atribut ini menggunakan perangkat lunak/applikasi IBM SPSS Statistics 24. Penggunaan perangkat lunak/applikasi tersebut akan menghasilkan 8 kombinasi atribut-atribut yang telah ditentukan. Proses pembuatan kombinasi/stimuli ini dilakukan pada masingmasing aspek integrasi yang telah ditetapkan. 
Tabel 5.

Stimuli/Kombinasi untuk Aspek Integrasi Sosial

\begin{tabular}{|c|c|c|c|c|}
\hline Pilihan & Keamanan & Kenyamanan & Waktu Tunggu & Ranking \\
\hline A & CCTV & $\begin{array}{l}\text { Ditunjang dari Fasilitas di dalam } \\
\text { angkutan }\end{array}$ & Maksimal 15 menit & \\
\hline B & CCTV & $\begin{array}{l}\text { Ditunjang dari Keramahan dan } \\
\text { keahlian awak/pengemudi }\end{array}$ & Maksimal 15 menit & \\
\hline $\mathrm{C}$ & CCTV & $\begin{array}{l}\text { Ditunjang dari Keramahan dan } \\
\text { keahlian awak/pengemudi }\end{array}$ & Maksimal 26 menit & \\
\hline $\mathrm{D}$ & $\begin{array}{l}\text { CCTV dan pemisahan } \\
\text { tempat duduk }\end{array}$ & $\begin{array}{l}\text { Ditunjang dari Keramahan dan } \\
\text { keahlian awak/pengemudi }\end{array}$ & Maksimal 15 menit & \\
\hline $\mathrm{E}$ & $\begin{array}{l}\text { CCTV dan pemisahan } \\
\text { tempat duduk }\end{array}$ & $\begin{array}{l}\text { Ditunjang dari Keramahan dan } \\
\text { keahlian awak/pengemudi }\end{array}$ & Maksimal 26 menit & \\
\hline $\mathrm{F}$ & $\begin{array}{l}\text { CCTV dan pemisahan } \\
\text { tempat duduk }\end{array}$ & $\begin{array}{l}\text { Ditunjang dari Fasilitas di dalam } \\
\text { angkutan }\end{array}$ & Maksimal 15 menit & \\
\hline G & $\begin{array}{l}\text { CCTV dan pemisahan } \\
\text { tempat duduk }\end{array}$ & $\begin{array}{l}\text { Ditunjang dari Fasilitas di dalam } \\
\text { angkutan }\end{array}$ & Maksimal 26 menit & \\
\hline $\mathrm{H}$ & CCTV & $\begin{array}{l}\text { Ditunjang dari Fasilitas di dalam } \\
\text { angkutan }\end{array}$ & Terhubung seluruh angkutan & \\
\hline
\end{tabular}

Tabel 6.

Nilai Utility dari Indikator Integrasi Fisik

\begin{tabular}{|c|c|c|c|}
\hline \multicolumn{4}{|c|}{ Utilities } \\
\hline & & $\begin{array}{c}\text { Utility } \\
\text { Estimate }\end{array}$ & $\begin{array}{l}\text { Std. } \\
\text { Error }\end{array}$ \\
\hline \multirow{2}{*}{ Desain Stasiun/Titik Transfer } & Mempermudah perpindahan ke kendaraan pribadi &,- 258 & 152 \\
\hline & Mempermudah perpindahan ke angkutan umum lain &, 258 & 152 \\
\hline \multirow{2}{*}{ Fasilitas Pejalan Kaki } & Prioritas keamanan &,- 253 & 152 \\
\hline & Prioritas kenyamanan &, 253 &, 152 \\
\hline \multirow{2}{*}{ Jaringan } & Terhubung dengan seluruh angkutan & 169 & 152 \\
\hline & Terhubung dengan seluruh angkutan dan park and ride &,- 169 &, 152 \\
\hline
\end{tabular}

Tabel 7.

Importance Values dari Indikator Integrasi Fisik

\begin{tabular}{lc}
\hline \multicolumn{2}{c}{ Importance Values } \\
\hline Desain Stasiun/Titik & 49,424 \\
Transfer & 22,562 \\
Fasilitas Pejalan Kaki & 28,013 \\
Jaringan & \\
Avaeraged Important Score & \\
\hline \hline
\end{tabular}

3) Pengumpulan data hasil penilaian oleh para responden yang telah memberi ranking berdasarkan preferensinya.

Penilaian oleh para responden dilakukan dengan memberikan ranking atau urutan kepada sejumlah kombinasi yang telah ditetapkan sebelumnya. Responden memberikan ranking antara nilai 1 hingga nilai 8 . Angka 1 merepresentasikan pilihan (kombinasi) yang paling tidak sesuai, sedangkan angka 8 merepresentasikan pilihan yang paling sesuai. Dalam kata lain, semakin besar nilai ranking yang diberikan, semakin besar preferensi responden terhadap pilihan tersebut.

4) Proses analisis conjoint yang menghasilkan nilai utility dan importance value.

Hasil pengisian kuisioner yang telah dilakukan oleh responden akan diproses kembali dengan perangkat lunak/applikasi IBM SPSS Statistics 24 dan akan menghasilkan nilai utility dan importance value. Kedua nilai tersebut adalah representasi dari preferensi masyarakat.

\section{HASIL DAN PEMBAHASAN}

\section{A. Identifikasi Variabel Integrasi dalam Pengembangan Feeder Suroboyo Bus}

Sebelum mencaritahu preferensi masyarakat, variabel integrasi dalam pengembangan Feeder Suroboyo Bus perlu diidentifikasi terlebih dahulu. Hasil identifikasi tersebut yang nantinya akan dijadikan pilihan-pilihan yang dinilai oleh masyarakat sehingga preferensi mereka dapat diketahui.
Proses identifikasi tersebut melibatkan wawancara dengan beberapa personel Dinas Perhubungan Kota Surabaya yang memiliki tanggung jawab/wewenang atas pengembangan feeder Suroboyo Bus. Pada penelitian ini, narasumbernarasumber tersebut diwawancarai dan hasil transkrip wawncara tersebut akan diproses dengan menggunakan analisis Content. Hasil dari analisis Content tersebut ditujukan untuk menggali sejumlah opsi/pilihan pengembangan feeder Suroboyo Bus dalam bentuk atribut dan level. Hasil dari proses tersebut ditunjukkan pada Tabel 2.

Berdasarkan Tabel 2, bisa diketahui bahwa setiap aspek terdiri atas sejumlah atribut yang berbeda di mana aspek integrasi fisik memiliki 3 atribut, integrasi operasional memiliki 4 atribut, dan integrasi sosial yang memiliki 3 atribut. Setiap atribut yang telah disebutkan memiliki 2 level yang menyatakan pilihan/opsi yang akan diberikan kepada masyarakat/responden.

Atribut dan level yang telah ditentukan akan dibuat stimuli/kombinasi. Pembuatan stimuli/kombinasi tersebut dilakukan pada masing-masing aspek, sehingga dihasilkan 3 stimuli yang terdiri atas 1 stimuli integrasi fisik, 1 stimuli integrasi operasional, dan 1 integrasi sosial. Hasil stimuli yang telah dibuat dapat ditunjukkan oleh Tabel 3, 4, dan 5.

\section{B. Preferensi Masyarakat terhadap Variabel-Variabel} Pengembangan Feeder Suroboyo Bus Berbasis Integrasi

Hasil mengenai preferensi masyarakat di dalam penelitian ini dapat dilihat dari nilai utility dan importance value pada setiap atribut dan level di masing-masing indikator. Nilai utility merupakan nilai yang menggambarkan seberapa besar preferensi individu terhadap sebuah objek. Dapat dikatakan bahwa masyarakat memilih sebuah objek/level ketika nilai utility yang dimiliki objek/level tersebut bernilai positif dan sebaliknya. Importance Value di sisi lain, merupakan tolak ukur kepentingan sebuah atribut terhadap atribut lainnya. 
Tabel 8.

Nilai Utility dari Indikator Integrasi Operasional

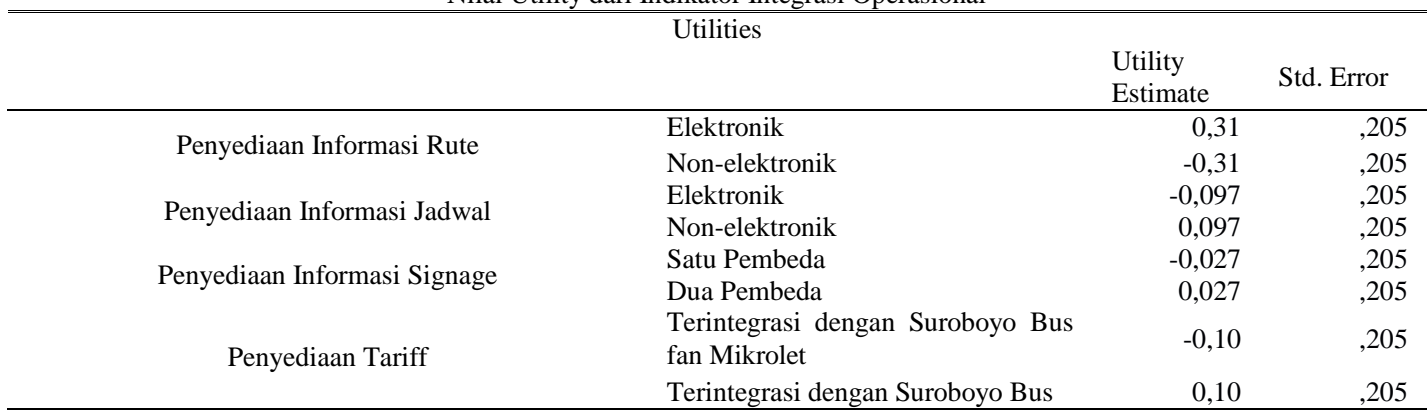

Tabel 9.

Importance Values dari Indikator Integrasi Operasional

\begin{tabular}{lr}
\hline \hline & \\
\hline Penyediaan Informasi Rute & Importance Values \\
Penyediaan Informasi Jadwal & 22,914 \\
Penyediaan Informasi Signage & 25,130 \\
Penyediaan Tariff & 18,170 \\
Avaeraged Important Score & \\
\hline \hline
\end{tabular}

Tabel 10

Nilai Utility dari Indikator Integrasi Sosial

\begin{tabular}{|c|c|c|c|}
\hline \multicolumn{4}{|c|}{ Utilities } \\
\hline & & $\begin{array}{c}\text { Utility } \\
\text { Estimate }\end{array}$ & $\begin{array}{l}\text { Std. } \\
\text { Error }\end{array}$ \\
\hline \multirow{2}{*}{ Keamanan } & Penyediaan CCTV &,- 20 & ,095 \\
\hline & Penyediaan CCTV dan pemisahan tempat duduk & ,20 & 095 \\
\hline \multirow{2}{*}{ Kenyamaanan } & Ditunjang oleh Fasilitas di dalam Angkutan &, 031 & ,095 \\
\hline & Ditunjang oleh keramahan dan keahlian awak/pengemudi &,- 031 & ,095 \\
\hline \multirow{2}{*}{ Waktu Tunggu } & Maksimal 15 Menit &,- 316 & ,095 \\
\hline & Maksimal 26 Menit & ,316 & ,095 \\
\hline
\end{tabular}

Tabel 11 .

Importance Values dari Indikator Integrasi Sosial

\begin{tabular}{lr}
\multicolumn{2}{c}{ Importance Values } \\
\hline \hline Keamanan & 29,809 \\
Kenyamaanan & 31,993 \\
Waktu Tunggu & 37,208 \\
Avaeraged Important Score & \\
\hline \hline
\end{tabular}

Semakin besar nilai importance value, semakin besar anggapan masyarakan akan pentingnya sebuah atribut.

1) Integrasi Fisik

Gambaran dari preferensi masyarakat terhadap konsep integrasi fisik pengembangan feeder Suroboyo Bus ditunjukkan pada Tabel 6.

Berdasarkan nilai utility, variabel integrasi fisik yang menjadi preferensi masyarakat meliputi,

1. Desain stasiun/Titik transfer yang menawarkan kemudahan berpindah ke angkutan umum lain,

2. Fasilitas pejalan kaki dengan prioritas kenyamaanan,

3. Jaringan yang terhubung ke seluruh angkutan.

Hasil penghitungan Importance Value, pada indikator integrasi fisik ditunjukkan pada Tabel 7.

Berdasarkan Tabel 7, bisa dilihat bahwa atribut desain stasiun/titik transfer merupakan atribut dari integrasi fisik yang dianggap paling penting oleh masyarakat.

\section{2) Integrasi Operasional}

Gambaran dari preferensi masyarakat terhadap konsep integrasi fisik pengembangan feeder Suroboyo Bus ditunjukkan pada Tabel 8.

Berdasarkan nilai utility, variabel integrasi operasional yang menjadi preferensi masyarakat meliputi,

1. Penyediaan informasi rute secara elektronik

2. Penyediaan informasi jadwal secara non-elektronik

3. Penyediaan informasi signage dengan dua pembeda
4. Penyediaan tariff yang terintegrasi dengan Suroboyo Bus

Hasil penghitungan Importance Value, pada indikator integrasi operasional ditunjukkan pada Tabel 9. Berdasarkan Tabel 9, bisa dilihat bahwa atribut waktu tunggu merupakan atribut dari integrasi sosial yang dianggap paling penting oleh masyarakat.

\section{3) Integrasi Sosial}

Gambaran dari preferensi masyarakat terhadap konsep integrasi fisik pengembangan feeder Suroboyo Bus ditunjukkan pada Tabel 10. Berdasarkan nilai utility, variabel integrasi sosial yang menjadi preferensi masyarakat meliputi,

1. Keamanan yang ditunjang melalui penyediaan CCTV dan pemisahan tempat duduk

2. Kenyamanan yang ditunjang oleh fasilitas di dalam angkutan

3. Waktu tunggu maksimal 26 menit

Hasil penghitungan Importance Value, pada indikator integrasi fisik ditunjukkan pada Tabel 11.

Berdasarkan Tabel 11, bisa dilihat bahwa atribut waktu tunggu merupakan atribut dari integrasi sosial yang dianggap paling penting oleh masyarakat.

\section{KESIMPULAN}

Berdasarkan hasil analisis dan pembahasan yang telah dilakukan pada penelitian ini, maka dapat diambil beberapa kesimpulan sebagai berikut:.

1. Preferensi masyarakat terhadap integrasi fisik dalam pengembangan feeder Suroboyo Bus terdiri atas desain stasiun/Titik transfer yang menawarkan kemudahan berpindah ke angkutan umum lain, fasilitas pejalan kaki dengan prioritas kenyamaanan, jaringan yang terhubung ke seluruh angkutan 
2. Preferensi masyarakat terhadap integrasi operasional dalam pengembangan feeder Suroboyo Bus terdiri atas penyediaan informasi rute secara elektronik, penyediaan informasi jadwal secara non-elektronik, penyediaan informasi signage dengan dua pembeda, penyediaan tariff yang terintegrasi dengan Suroboyo Bus

3. Preferensi masyarakat terhadap integrasi sosial dalam pengembangan feeder Suroboyo Bus terdiri atas keamanan yang ditunjang melalui penyediaan CCTV dan pemisahan tempat duduk, kenyamanan yang ditunjang oleh fasilitas di dalam angkutan, dan waktu tunggu maksimal 26 menit

4. Pengembangan angkutan feeder Suroboyo Bus disarankan untuk berfokus pada desain stasiun/titik transfer untuk aspek integrasi fisik, penyediaan informasi rute untuk aspek integrasi operasional waktu tunggu untuk aspek integrasi sosial.

\section{DAFTAR PUSTAKA}

[1] F. Szymon and J. Zak, "Planning of an integrated urban transportation system based on macro - simulation and MCDM/A methods," in Procedia Social and Behavioral Science 13, 2012.

[2] Dinas Perhubungan Kota Surabaya, "Laporan Akhir Rencana Sistem Angkutan Umum Kota Surabaya,” Surabaya, 2012.

[3] N. Katarzyna and S. Katarzyna, "Application of AHP method for multicriteria evaluation of variants of the integration of urban public transport," Transp. Res. Procedia, vol. 3, 2014.

[4] K. Saliara, "Public Transport Integration: the Case Study of Thessaloniki," Transp. Res. Procedia, vol. 4, 2014.

[5] Public Transport Integration and Transit Alliances, "Deutsche Gesellschaft für Internationale Zusammenarbeit (GIZ),” 2017.

[6] G. R. Ramadhan and I. Buchori, "Strategi Integrasi Sistem Transportasi Umum Dalam Menunjang Pariwisata Kota Yogyakarta,” J. Pembang. Kota, 2018.

[7] S. Stolovia and L. Kunchev, Study of criteria for evaluation of transportation with intermodal transport. ResearchGate, 2017.

[8] K. Krippendorff, Content Analysis an Introduction to its Metodology, 2nd ed. London: Sage Publications, 2004.

[9] Apriyanti, "Analisis Conjoint Preferensi Konsumen Terhadap Kombinasi Fitur Produk Motor Bekas Berdasarkan Segmen Gender Di Jambi," J. Winners, vol. 14, no. 2, 2013. 